\title{
A scoping review of the moral experiences of children with medical complexity in Brazil
}

\author{
Uma revisão de escopo das vivências morais de crianças com complexidade médica no Brasil \\ Una revisión de alcance de las experiencias morales de niños con complejidad médica en Brasil
}

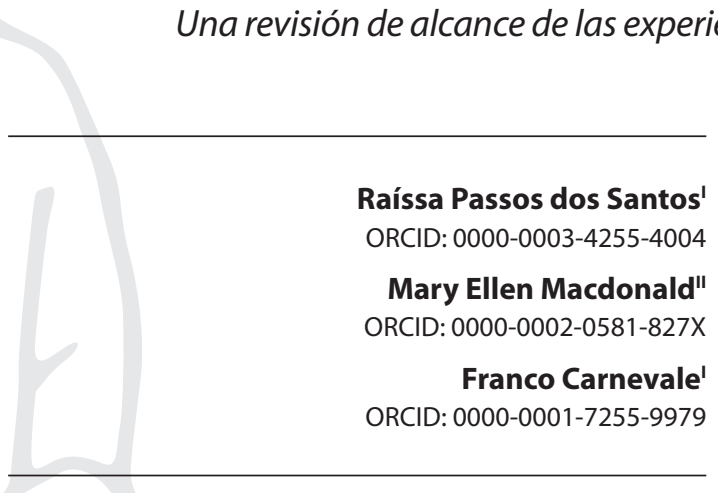

'.McGill University, Ingram School of Nursing. Montreal, Quebec, Canada.

".McGill University, Faculty of Dentistry. Montreal, Quebec, Canada.

How to cite this article: Santos RP, Macdonald ME, Carnevale F. A scoping review of the moral experiences of children with medical complexity in Brazil. Rev Bras Enferm. 2020;73(2):e20190268. doi: http://dx.doi.org/10.1590/0034-7167-2019-0268

Corresponding Author:

Raissa Passos dos Santos

E-mail: raissa.santos@mail.mcgill.ca

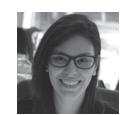

EDITOR IN CHIEF: Dulce Aparecida Barbosa ASSOCIATE EDITOR: Antonio José de Almeida Filho

Submission: $03-23-2019$

Approval: 11-28-2019

\begin{abstract}
Objectives: The aim of this review was to identify and summarize how the moral experiences of children with medical complexity are being expressed within the Brazilian health-related literature and discuss research gaps and directions for future research. Methods: A scoping review was performed using the methodological framework of Arksey and O'Malley and the Preferred Reporting Items for Systematic reviews and Meta-Analyses extension for Scoping Reviews (PRISMA-ScR). Systematic searches were conducted on Medline, CINAHL, Scopus, and Embase databases. Articles were included if using qualitative methodologies, having children as participants, and published in Brazil. Results: In total, 6,360 articles were retrieved from databases. Sixteen studies were selected for the analysis. Final considerations: The studies were not primarily focused on children's moral experiences. Yet, the studies demonstrate morally relevant accounts concerning children's capacity to reason and interpret their lived experiences, expressing deep concerns about isolation, suffering, future aspirations, and feelings of normality.
\end{abstract}

Descriptors: Review; Child; Child Health; Disabled Children; Ethics.

\section{RESUMO}

Objetivos: O objetivo desta revisão foi identificar e sintetizar como as vivências morais de crianças com complexidade médica estão sendo expressas na literatura brasileira relacionada à saúde e discutir lacunas de pesquisa e orientações para pesquisas futuras. Métodos: Uma revisão de escopo foi realizada, usando o referencial metodológico de Arksey e O'Malley, os Itens de Relatórios Preferenciais para Revisões Sistemáticas e a extensão de Meta-Análises para Revisões de Escopo (PRISMA-ScR). Pesquisas sistemáticas foram conduzidas nos bancos de dados Medline, CINAHL, Scopus e Embase. Os artigos foram incluídos de acordo com os critérios: possuir metodologias qualitativas, crianças como participantes e pesquisas publicadas no Brasil. Resultados: No total, 6.360 artigos foram recuperados dos bancos de dados. Dezesseis estudos foram selecionados para a análise. Considerações finais: Os estudos analisados não estavam focados primariamente nas experiências morais das crianças. No entanto, os estudos demonstram relatos moralmente relevantes sobre a capacidade das crianças de raciocinar e interpretar suas experiências vividas, expressando profundas preocupações sobre isolamento, sofrimento, aspirações futuras e sentimentos de normalidade.

Descritores: Revisão; Criança; Saúde da Criança; Crianças com Deficiência; Ética.

\section{RESUMEN}

Objetivos: identificar y sintetizar cómo se expresan las experiencias morales de los niños con complejidad médica en la literatura brasileña relacionada con la salud y discutir las brechas de investigación y las directrices para futuras investigaciones. Métodos: se realizó una revisión de alcance utilizando el marco metodológico de Arksey y O'Malley, los elementos de informes preferidos para las revisiones sistemáticas y la extensión de la declaración de PRISMA (Preferred Reporting Items for Systematic Reviews and Meta-Analyses) para las revisiones de alcance (PRISMA-ScR). Se realizaron búsquedas sistemáticas en las bases de datos Medline, CINAHL, Scopus y Embase. Los artículos se incluyeron según los criterios: con metodologías cualitativas, niños como participantes e investigaciones publicadas en Brasil. Resultados: en total, se recuperaron 6.360 artículos de las bases de datos. Dieciséis estudios fueron seleccionados para el análisis. Consideraciones finales: los estudios analizados no se centraron principalmente en las experiencias morales de los niños. Sin embargo, los estudios demuestran relatos moralmente relevantes sobre la capacidad de los niños para razonar e interpretar sus experiencias vividas, expresando profundas preocupaciones sobre el aislamiento, el sufrimiento, las aspiraciones futuras y los sentimientos de normalidad.

Descriptores: Revisión; Niños; Salud Infantil; Niños con Discapacidades; Ética. 


\section{INTRODUCTION}

Children with medical complexity are a heterogeneous group of children who have severe and chronic health conditions, substantial health service needs, functional limitations, and high health resource utilization ${ }^{(1)}$. This population of children have complex chronic conditions that affect their everyday lives ${ }^{(2)}$. In Brazil, over last 20 years, these children are a new reality after the significant decrease in child mortality rates and subsequent survival of children with complex health conditions, such as extreme prematurity and congenital malformations ${ }^{(3)}$.

Brazilian nursing research has shown that these children and their families are living in vulnerable conditions which create barriers to health-care services and decrease their quality of care and life ${ }^{(4)}$. These vulnerable conditions lead to significant ethical concerns such as health inequities and discrimination, inadequate public policies, and exclusion of children from decisions that affect them ${ }^{(4,5)}$.

From an ethical perspective, legal documents and standards in Brazil have described the importance of children's participation in decisions involving them ${ }^{(6)}$. Brazilian legislation stresses that children must be included, and their views must be taking into consideration in decisions such as medical treatments ${ }^{(6)}$. In addition, the recognition of children's perspectives and preferences have been described in the childhood research field as a strategy to promote more inclusive practices that can meet their needs and promote equitable care ${ }^{(7)}$. In addition, studies have shown that to illuminate the multiple facets of children's experiences, healthcare professionals and researchers should draw on frameworks that acknowledge children's capacity to act as agents, reasoning and interpreting their own lived experiences $^{(8)}$. These interpretations, which are rooted in collective notions of what is good, just, and right, can be explored through the use of a moral experiences framework ${ }^{(9)}$. This framework focuses on how persons live out their moral lives. Moral experiences have been defined by Hunt and Carnevale ${ }^{(9)}$ as "a person's sense that values that he or she deems important are being realized or thwarted in everyday life, including interpretations of a lived encounter, or a set of lived encounters, that fall on spectrum of right-wrong, good-bad or just-unjust" (p. 659).

There is therefore emerging evidence in the childhood research field about the importance of the analysis of children's moral experiences to understand their moral lives ${ }^{(7)}$. However, we know little about how the health-related literature is reporting the moral experiences of children with medical complexity in Brazil. Thus, the objective of this review was to (a) identify and summarize how the moral experiences of children with medical complexity are being expressed within the Brazilian health-related literature, and (b) discuss research gaps and directions for future research.

\section{OBJECTIVE}

To (a) identify and summarize how the moral experiences of children with medical complexity are being expressed within the Brazilian health-related literature, and (b) discuss research gaps and directions for future research.

\section{METHODS}

Because moral experience is an emerging framework in healthrelated research, a scoping review synthesis method, based upon the model of Arksey and O'Malley ${ }^{(10)}$ was chosen as a methodology. Scoping review methodology allows an assessment of emerging evidence, thereby providing significant foundation for future research ${ }^{(11)}$. As a comprehensive methodology to examine relevant literature on a research area, scoping reviews have the aim of examining the extent, range, and nature of research activity as well as identifying research gaps in the existing literature ${ }^{(10)}$. This methodology includes five essential steps: 1) identification of the research question; 2) identification of relevant studies; 3 ) selection of studies for review; 4) charting the data; and 5) collating, summarizing, and reporting the results. The steps were conducted as follows:

\section{Step 1: Identification of the research question}

Given that there is some available literature on the moral experiences of children with medical complexity in Brazil, but it has not yet been summarized or synthesized, the research question was: What is known from the existing health-related literature in Brazil about the moral experiences of children with medical complexity?

\section{Step 2: Identification of relevant studies}

The studies were identified through a systematic search initially completed in May 27, 2015. The searches were rerun in July 10, 2018 with entry date from May 27, 2015 onwards. Four computerized databases were used: CINAHL, Ovid Medline, Embase, and Scopus. The search strategy was developed with input from a health sciences research librarian. The search strategy included terms related to health, children, and qualitative studies. The complete description of the search strategy is presented in Chart 1.

Chart 1 - Search strategy

\begin{tabular}{|c|c|c|}
\hline Database & Search strategy & Results \\
\hline Ovid Medline & 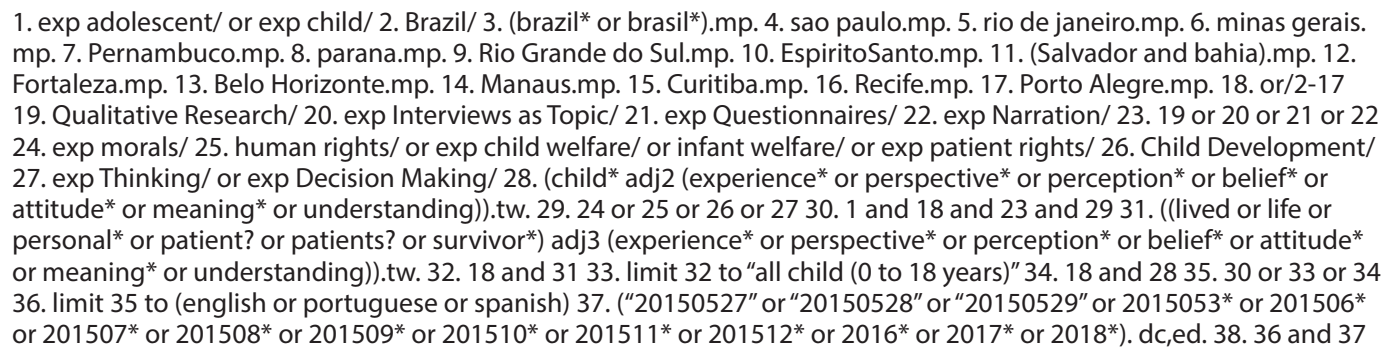 & $\begin{array}{c}2891 \\
\text { articles }\end{array}$ \\
\hline
\end{tabular}




\begin{tabular}{|c|c|c|}
\hline Database & Search strategy & Results \\
\hline CINAHL & $\begin{array}{l}\text { S1. brazil* or brasil* or sao paulo or rio de janeiro or minas gerais or Pernambuco or parana or Rio Grande do Sul or } \\
\text { Espirito Santo or Fortaleza or Belo Horizonte or Manaus or Curitiba or Recife or Porto Alegre or (Salvador and bahia) S2. } \\
\text { infan* or child* or youth* or minors or boy or boys or girl or girls or preschool* or school age\$1 or toddler* or pediatric* } \\
\text { or paediatric* or puberty or pubescen* or young people or young person or teen* or adolescen* or juvenile S3. S1 } \\
\text { AND S2 S4. (MH "Psychology, Social+") S5. (MH "Human Rights+") OR (decision making or moral or morals or ethic* } \\
\text { or rights or welfare or advoca*) S6. (MH "Child Development") OR (MH "Infant Development") S7. (MH "Thinking+") } \\
\text { OR (MH "Decision Making+") S8. (lived or life or personal or patient* or survivor*) N3 (experience* or perspective* } \\
\text { or perception* or belief* or attitude* or meaning* or understanding) S9. S4 OR S5 OR S6 OR S7 OR S8 S10. S3 AND } \\
\text { S9 S11. (MH "Qualitative Studies+") S12. (MH "Focus Groups") OR (MH "Interviews+") OR (MH "Narratives") OR (MH } \\
\text { "Observational Methods+") S13. mixed N1 (method* or studies S14. qualitative or interview or lived experience S15. } \\
\text { qualitative or interview or focus group* or grounded theor* or phenomenolog* or narrat* or verbal communication or } \\
\text { voice or conversation* or discourse* or ethnograph* or ethnomethodolog* or autoethnograph* or hermeneutic* or } \\
\text { constructivis* S16. key N1 informant* S17. (thematic or content) N1 analys* S18. (action or participatory) N1 research } \\
\text { S19. S11 OR S12 OR S13 OR S14 OR S15 OR S16 OR S17 OR S18 S20. S10 AND S19 }\end{array}$ & $\begin{array}{c}2257 \\
\text { articles }\end{array}$ \\
\hline Scopus & $\begin{array}{l}\text { (TITLE-ABS-KEY ("mental capacity" OR "mental competen*" OR "decision making") AND TITLE-ABS-KEY (ethic* OR } \\
\text { "informed consent" OR "moral development" OR moral*) AND TITLE-ABS-KEY (infant* OR infancy OR child* OR } \\
\text { youth* OR minor OR minors OR boy OR boys OR girl OR girls OR preschool* OR school AND age } 1 \text { OR toddler* } \\
\text { OR pediatric* OR paediatric* OR young AND people OR teen* OR adolescen* OR juvenile) AND PUBYEAR > 1994 } \\
\text { ) AND ORIG-LOAD-DATE > } 20150409\end{array}$ & $\begin{array}{c}726 \\
\text { articles }\end{array}$ \\
\hline Embase & 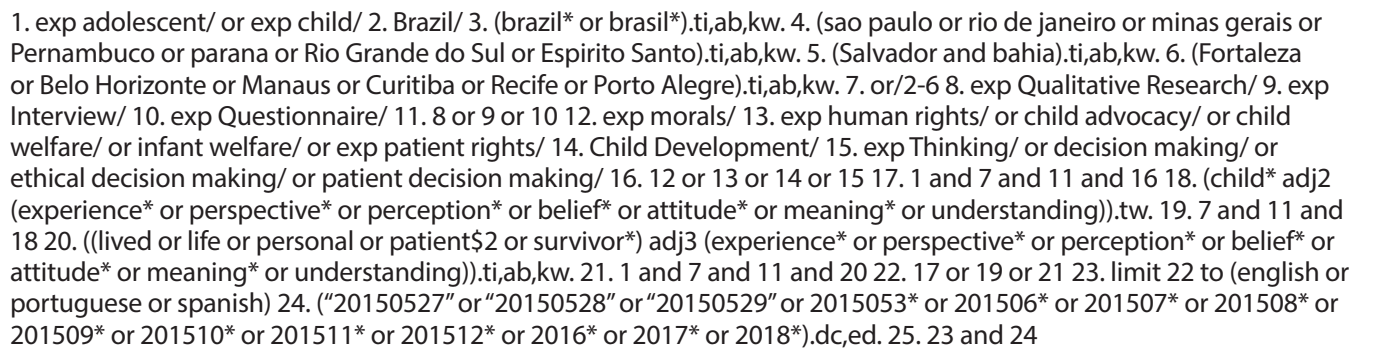 & $\begin{array}{c}486 \\
\text { articles }\end{array}$ \\
\hline
\end{tabular}

\section{Step 3: Selection of studies for review}

Articles were selected based on the following inclusion criteria:

1. Children were included as participants in the study. This criterion was used in order to ascertain that the examination of children's views and perspectives was done through the analysis of their own accounts.

2. Empirical, qualitative studies. Hunt and Carnevale ${ }^{(9)}$ suggest that, because of the hermeneutical nature of the concept of moral experience (e.g., the aim of understanding a particular phenomenon through interpretation of the different aspects that shape people's experiences), studies on moral experiences should be primarily qualitative. Therefore, qualitative studies were included in this analysis to ensure they were confirming with the aspects of moral experiences.

3. Studies conducted in Brazil. According to Hunt and Carnevale ${ }^{(9)}$, the particular social context in which experiences are lived has an important influence on people's choices and preferences. Therefore, the moral experiences of children with medical complexity in Brazil will have significant characteristics that must be addressed within the particularities of the Brazilian health context.

4. Articles published in Portuguese, English, and Spanish languages between the years 1994 and 2018. The year 1994 was chosen in consideration of the approval of the Brazilian Child and Adolescent Statute by the decree 1.302, which stated, for the first time in Brazil's democratic regime, the rights of all children across the nation $^{(12)}$.

The definition used in this analysis for the term "children" drew on the United Nations Conventions on the Rights of the Child, which refers to children as all minors from 0 to 17 years of age.
Medical complexity was identified by matching participants health conditions with the definition of medical complexity described by Cohen et al ${ }^{(1)}$ as "children who have clinical conditions that require health care needs such as medical care, specialized therapy, and educational needs with high utilization of health resources due to chronic conditions or functional limitations."

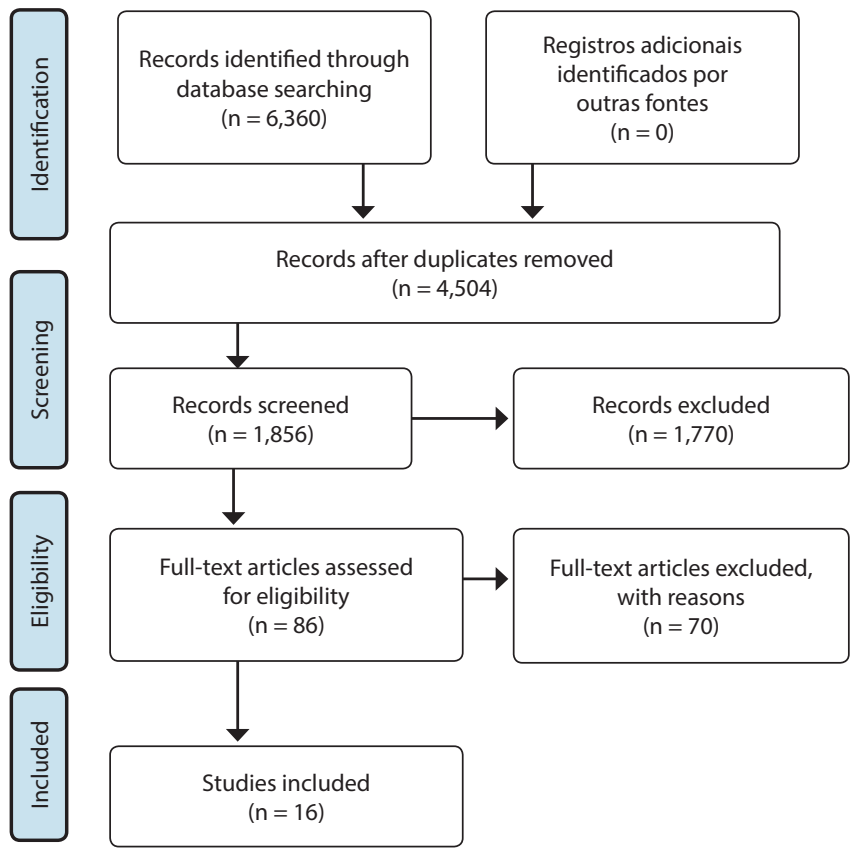

Figure 1 - Process of identification and inclusion of studies - Preferred Reporting Items for Systematic Reviews and Meta-Analyses (PRISMA) flow diagram 
PRISMA Extension for Scoping Reviews (PRISMA-ScR) was used to organize the systematic process of including articles in the analysis ${ }^{(13)}$. Articles selected for the analysis were screened by their titles in order to have a more comprehensive list of the literature. 86 articles were then selected for complete reading and further screening for relevance. 70 articles were excluded because they were reporting children's experiences through data collected with parents, included people with more than 18 years of age in the sample, or were not focus on the experiences of children. Therefore, the final selection included 16 articles. All 16 articles were included in the review. The selection of articles is presented in a flow diagram (Figure 1).

\section{Step 4: Charting the data}

Information from the selected articles was organized for analysis using the following categories: authors, year of publication, child's medical condition, aims of the study, specific methodology (e.g., how children's voices were accessed by the study), results and interpretation of the studies analyzed (e.g., how children's moral experiences are being expressed by the study), and themes related to the results of the analysis. Complete data charting information is presented in Chart 2.

\section{Step 5: Collating, summarizing, and reporting the results}

The articles analyzed in this review were first summarized according to the information gathered from the data charting. Following, a thematic analysis was conducted using the framework of moral experiences to identify relevant themes, analyze and interpret the data. (Chart 2). After the primary scanning of the articles' abstracts, we noticed that none of the studies explicitly conceptualized the experiences of children as moral experiences. However, across all the retained studies we noted investigations of children's morally relevant experiences. For example, there were statements from researchers that expressed the importance of recognizing children's voices in relation to health experiences.

Because of this lack of explicit use of the framework of moral experiences, for the purposes of this analysis children's moral experiences were explored very broadly. The moral experiences of children were primarily interpreted via expressions of "meaningful" experiences. By meaningful, we refer to the experiential significance ${ }^{(14)}$ which children attributed to their experiences. Therefore, our analysis is focused on demonstrating how the authors expressed moral experiences of children with medical complexity through the identification of the described health experiences that were most meaningful for children, touching on questions associated with their health conditions and notions of what is right, just, and good ${ }^{(9)}$. These experiences were described by our analysis in situations in which children were able to express interpretations, concerns, and preferences related to their complex health conditions.

\section{RESULTS}

In total, 6,360 articles were retrieved from CINAHL ( $n=2,257$ articles), Medline ( $n=2,891)$, Embase Brazil $(n=486)$, and Scopus $(n=726)$. After the removal of duplicate articles and the application of the inclusion criteria, 16 studies were retained for analysis ranging from the years 2000 to 2014. Regarding children's medical conditions, the studies explored the lived experiences of children living with HIV $(n=7)$, hemodialysis $(n=2)$, cancer $(n=2)$, sickle cell anemia $(n=1)$, and diabetes $(n=4)$. Children's ages ranged from 3 to 18 years. 15 studies were conducted by nursing researchers, and one by a physician. Articles were published in Portuguese.

Studies used unique terms to describe the experiences of children with medical complexity. Most of the terms used were related to the daily experiences of children; that is, how children perceive their daily lives within the perspectives of their clinical conditions. Terms used included: (translated from Portuguese) children's choices, responsibilities, meanings that children attribute to their conditions, lived experiences of children, lived suffering during an illness process, children's perceptions of the illness process, children's understandings about situations related to the illness, children's emotions as distress, and children's report on the implications of their conditions. Importantly, studies were not primarily focused on children's moral experiences, demonstrating a research gap that will be presented in the discussion section of this article. The data of the studies is charted in Chart 2, including title, authors, year of publication, medical condition, child's age, aim, specific methodological approach, and important results.

Chart 2 - Synthesis of research results

\begin{tabular}{|c|c|c|c|c|c|c|}
\hline Article title & $\begin{array}{c}\text { Authors/Year of } \\
\text { Publication }\end{array}$ & $\begin{array}{l}\text { Medical } \\
\text { Condition }\end{array}$ & $\begin{array}{l}\text { Child's } \\
\text { age }\end{array}$ & Aim & $\begin{array}{c}\text { Specific } \\
\text { Methodological } \\
\text { Approach }\end{array}$ & Important Results \\
\hline $\begin{array}{l}\text { A1. The voice of } \\
\text { children who } \\
\text { live with HIV on } \\
\text { implications of the } \\
\text { disease in their daily } \\
\text { life }\end{array}$ & $\begin{array}{c}\text { Kuyava J \& Pedro } \\
\text { ENR. } \\
(2014)\end{array}$ & HIV/AIDS & $\begin{array}{c}11 \text { to } 12 \\
\text { years }\end{array}$ & $\begin{array}{l}\text { Determine the } \\
\text { effects of HIV/AIDS } \\
\text { on the daily lives } \\
\text { of HIV-infected } \\
\text { children }\end{array}$ & $\begin{array}{l}\text { Exploratory } \\
\text { descriptive study } \\
\text { conducted through } \\
\text { semistructured } \\
\text { interviews }\end{array}$ & $\begin{array}{l}\text { Children with HIV live in } \\
\text { complex situations with } \\
\text { severe conflicts. However, } \\
\text { their childhood is similar to } \\
\text { that of other children without } \\
\text { the disease. }\end{array}$ \\
\hline $\begin{array}{l}\text { A2. HIV/AIDS } \\
\text { children living in } \\
\text { shelters under } \\
\text { the perspective of } \\
\text { humanistic nursing }\end{array}$ & $\begin{array}{l}\text { Medeiros HMF \& } \\
\text { Motta MGC. } \\
\text { (2008) }\end{array}$ & HIV/AIDS & $\begin{array}{l}\text { School } \\
\text { age (6 to } \\
12)\end{array}$ & $\begin{array}{l}\text { Understand the } \\
\text { experiences of HIV/ } \\
\text { AIDS children in } \\
\text { shelters }\end{array}$ & $\begin{array}{l}\text { Phenomenology } \\
\text { conducted through } \\
\text { unstructured interviews } \\
\text { under the perspective } \\
\text { of the humanistic } \\
\text { nursing theory }\end{array}$ & $\begin{array}{l}\text { Playing was considered } \\
\text { an activity that sustained } \\
\text { children's feelings of } \\
\text { "normality" and social } \\
\text { interactions. }\end{array}$ \\
\hline
\end{tabular}




\begin{tabular}{|c|c|c|c|c|c|c|}
\hline Article title & $\begin{array}{c}\text { Authors/ Year of } \\
\text { Publication }\end{array}$ & $\begin{array}{l}\text { Medical } \\
\text { Condition }\end{array}$ & $\begin{array}{l}\text { Child's } \\
\text { age }\end{array}$ & Aim & $\begin{array}{c}\text { Specific } \\
\text { Methodological } \\
\text { Approach }\end{array}$ & Important Results \\
\hline $\begin{array}{l}\text { A3. Child with HIV/ } \\
\text { AIDS: perceptions } \\
\text { of antiretroviral } \\
\text { treatment }\end{array}$ & $\begin{array}{c}\text { Motta MGC, } \\
\text { Pedro ENR, } \\
\text { Neves ET, et al. } \\
\text { (2012) }\end{array}$ & HIV/AIDS & $\begin{array}{l}5 \text { to } 10 \\
\text { years }\end{array}$ & $\begin{array}{l}\text { Uncover the } \\
\text { perceptions and } \\
\text { life experience of } \\
\text { the child regarding } \\
\text { antiretroviral } \\
\text { treatment }\end{array}$ & $\begin{array}{l}\text { Descriptive study } \\
\text { conducted through } \\
\text { creative sensitive } \\
\text { group dynamic }\end{array}$ & $\begin{array}{l}\text { Parents fear that discrimination } \\
\text { can isolate children; children } \\
\text { consider medications as a } \\
\text { good thing because they can } \\
\text { leave hospital and go home. }\end{array}$ \\
\hline $\begin{array}{l}\text { A4. Children living } \\
\text { with AIDS and their } \\
\text { experiences with } \\
\text { antiretroviral therapy }\end{array}$ & $\begin{array}{c}\text { Kuyava J, Pedro } \\
\text { ENR \& Botene } \\
\text { DZA. } \\
(2012)\end{array}$ & HIV/AIDS & $\begin{array}{l}9 \text { to } 11 \\
\text { years }\end{array}$ & $\begin{array}{l}\text { Find out how } \\
\text { children who live } \\
\text { with AIDS describe } \\
\text { their experiences } \\
\text { with antiretroviral } \\
\text { treatment }\end{array}$ & $\begin{array}{l}\text { Exploratory } \\
\text { descriptive study } \\
\text { conducted through } \\
\text { focus groups }\end{array}$ & $\begin{array}{l}\text { Children described their lives } \\
\text { as "normal" when they play and } \\
\text { go to school; medication is a } \\
\text { good thing because they do } \\
\text { not want to die; stigma about } \\
\text { HIV may lead to social isolation } \\
\text { and exclusion. }\end{array}$ \\
\hline $\begin{array}{l}\text { A5. Growing up with } \\
\text { HIV/AIDS: study on } \\
\text { adolescents with } \\
\text { HIV/AIDS and their } \\
\text { family caregivers }\end{array}$ & $\begin{array}{l}\text { Lima AAA \& } \\
\text { Pedro ENR. } \\
(2008)\end{array}$ & HIV/AIDS & $\begin{array}{l}11 \text { to } 14 \\
\text { years }\end{array}$ & $\begin{array}{l}\text { Identify how the } \\
\text { adolescent process } \\
\text { occurs, from the } \\
\text { perspective of } \\
\text { teenagers and their } \\
\text { families }\end{array}$ & $\begin{array}{l}\text { Descriptive study } \\
\text { conducted through } \\
\text { semistructured } \\
\text { interviews }\end{array}$ & $\begin{array}{l}\text { Adolescents' comparisons with } \\
\text { "healthy" adolescents may lead } \\
\text { to shame and sadness, feeling } \\
\text { of isolation. }\end{array}$ \\
\hline $\begin{array}{l}\text { A6. Adherence } \\
\text { to antiretroviral } \\
\text { therapy; experience } \\
\text { with scholars }\end{array}$ & $\begin{array}{c}\text { Martins SS \& } \\
\text { Martins TSS. } \\
\quad(2011)\end{array}$ & HIV/AIDS & $\begin{array}{l}6 \text { to } 11 \\
\text { years }\end{array}$ & $\begin{array}{l}\text { Describe the } \\
\text { adhering process } \\
\text { of scholars and } \\
\text { identify situations } \\
\text { they have lived that } \\
\text { may influence their } \\
\text { adherence to } \\
\text { antiretroviral therapy }\end{array}$ & $\begin{array}{l}\text { Descriptive study } \\
\text { conducted through } \\
\text { semistructured } \\
\text { interviews }\end{array}$ & $\begin{array}{l}\text { Use of medication is a good } \\
\text { thing because without it } \\
\text { they need to go to hospital; } \\
\text { children know about the side } \\
\text { effects of the medication and } \\
\text { consequences of not adhering } \\
\text { to treatment. }\end{array}$ \\
\hline $\begin{array}{l}\text { A7. The problem } \\
\text { of suffering; } \\
\text { perceptions by } \\
\text { adolescents with } \\
\text { cancer }\end{array}$ & $\begin{array}{c}\text { Menossi MJ \& } \\
\text { Lima, RAGA. } \\
\quad(2000)\end{array}$ & Cancer & $\begin{array}{l}12 \text { to } 17 \\
\text { years }\end{array}$ & $\begin{array}{l}\text { Identify the chief } \\
\text { causes of their } \\
\text { suffering, identified } \\
\text { in interviews with } \\
\text { patients themselves }\end{array}$ & $\begin{array}{l}\text { Exploratory } \\
\text { descriptive study } \\
\text { conducted through } \\
\text { semistructured } \\
\text { interviews }\end{array}$ & $\begin{array}{l}\text { Fear of death and isolation } \\
\text { because of the frequent need } \\
\text { of hospitalization; knowing } \\
\text { about treatment and health } \\
\text { procedures helps them to } \\
\text { collaborate. }\end{array}$ \\
\hline $\begin{array}{l}\text { A8. Sickle cell disease; } \\
\text { short communication } \\
\text { on how children } \\
\text { express through } \\
\text { games what it means } \\
\text { for them to have the } \\
\text { disease }\end{array}$ & $\begin{array}{c}\text { Souza AAM, } \\
\text { Ribeiro CA \& } \\
\text { Borba RIH. } \\
(2011)\end{array}$ & $\begin{array}{l}\text { Sickle cell } \\
\text { disease }\end{array}$ & $\begin{array}{l}3 \text { to } 12 \\
\text { years }\end{array}$ & $\begin{array}{l}\text { Understand the } \\
\text { significance of } \\
\text { sickle cell anemia in } \\
\text { children between } 3 \\
\text { and } 12 \text { years old }\end{array}$ & $\begin{array}{l}\text { Grounded theory } \\
\text { conducted through } \\
\text { interviews using } \\
\text { playing }\end{array}$ & $\begin{array}{l}\text { Pain and feeling of impotence } \\
\text { in the face of the disease lead } \\
\text { to sad feelings and social } \\
\text { isolation and exclusion. }\end{array}$ \\
\hline $\begin{array}{l}\text { A9. Adolescents } \\
\text { under hemodialysis; } \\
\text { phenomenological } \\
\text { study under the light } \\
\text { of ethical nursing } \\
\text { care }\end{array}$ & $\begin{array}{c}\text { Vieira, PR; } \\
\text { Rodrigues, BRDR. } \\
\text { (2007) }\end{array}$ & Hemodialysis & $\begin{array}{c}12 \text { to } 18 \\
\text { years }\end{array}$ & $\begin{array}{l}\text { Understand } \\
\text { the experience } \\
\text { undergone by } \\
\text { adolescents under } \\
\text { conventional } \\
\text { hemodialysis }\end{array}$ & $\begin{array}{l}\text { Phenomenology } \\
\text { conducted through } \\
\text { unstructured } \\
\text { interviews }\end{array}$ & $\begin{array}{l}\text { Having future aspirations and } \\
\text { keeping "normal" activities } \\
\text { such as playing and going } \\
\text { to school were described as } \\
\text { situations that help children to } \\
\text { face the disease and the sad } \\
\text { feelings about being sick. }\end{array}$ \\
\hline $\begin{array}{l}\text { A10. Quotidian } \\
\text { of teenagers } \\
\text { with leukemia; } \\
\text { the meaning of } \\
\text { chemotherapy }\end{array}$ & $\begin{array}{c}\text { Jesus, LKR; } \\
\text { Gonçalves, LLC. } \\
\text { (2006) }\end{array}$ & Cancer & $\begin{array}{l}10 \text { to } 18 \\
\text { years }\end{array}$ & $\begin{array}{l}\text { Unveil the meaning } \\
\text { of chemotherapy } \\
\text { to adolescents with } \\
\text { leukemia }\end{array}$ & $\begin{array}{l}\text { Phenomenology } \\
\text { conducted through } \\
\text { unstructured } \\
\text { interviews }\end{array}$ & $\begin{array}{l}\text { Body modifications such } \\
\text { as alopecia change the } \\
\text { way adolescents perceive } \\
\text { themselves and affect their } \\
\text { self-esteem, with consequent } \\
\text { feelings of shame and } \\
\text { isolation; medical treatment } \\
\text { was described as a good thing } \\
\text { because they can live longer. }\end{array}$ \\
\hline $\begin{array}{l}\text { A11. Living with } \\
\text { diabetes; the } \\
\text { experience as it is told } \\
\text { by children }\end{array}$ & $\begin{array}{c}\text { Moreira PL; } \\
\text { Dupas G. } \\
(2006)\end{array}$ & Diabetes & $\begin{array}{l}7 \text { to } 14 \\
\text { years }\end{array}$ & $\begin{array}{l}\text { Understand the } \\
\text { experiences of } \\
\text { children with the } \\
\text { disease }\end{array}$ & $\begin{array}{l}\text { Grounded theory } \\
\text { conducted through } \\
\text { unstructured } \\
\text { interviews }\end{array}$ & $\begin{array}{l}\text { Rapid life changes after } \\
\text { diagnosis lead to feelings of } \\
\text { sadness and isolation; fear } \\
\text { of getting sick and dying; } \\
\text { restrictions on eating and } \\
\text { activities lead to feelings } \\
\text { of exclusion and isolation; } \\
\text { questioning "why me." }\end{array}$ \\
\hline
\end{tabular}




\begin{tabular}{|c|c|c|c|c|c|c|}
\hline Article title & $\begin{array}{c}\text { Authors/Year of } \\
\text { Publication }\end{array}$ & $\begin{array}{l}\text { Medical } \\
\text { Condition }\end{array}$ & $\begin{array}{l}\text { Child's } \\
\text { age }\end{array}$ & Aim & $\begin{array}{c}\text { Specific } \\
\text { Methodological } \\
\text { Approach }\end{array}$ & Important Results \\
\hline $\begin{array}{l}\text { A12. School } \\
\text { experience of } \\
\text { children with } \\
\text { diabetes mellitus } \\
\text { expressed by } \\
\text { dramatic therapeutic } \\
\text { play }\end{array}$ & $\begin{array}{l}\text { La Banca, RO, } \\
\text { Monteiro, OO, } \\
\text { Ribeiro, CA, } \\
\text { Borba, RIH } \\
\text { (2015) }\end{array}$ & Diabetes & $\begin{array}{l}6 \text { to } 10 \\
\text { years }\end{array}$ & $\begin{array}{l}\text { To understand } \\
\text { the experience of } \\
\text { school children } \\
\text { through Dramatic } \\
\text { Therapeutic Play }\end{array}$ & $\begin{array}{l}\text { Qualitative descriptive } \\
\text { study }\end{array}$ & $\begin{array}{l}\text { Child's suffering with dietary } \\
\text { restriction. However, they } \\
\text { describe an optimism in face } \\
\text { of the disease, with important } \\
\text { considerations to playing as a } \\
\text { feeling of "normality". The use } \\
\text { of medication is a good thing } \\
\text { because it avoids getting sick } \\
\text { and hospitalization. }\end{array}$ \\
\hline $\begin{array}{l}\text { A13. Experiences of } \\
\text { Brazilian children } \\
\text { and family caregivers } \\
\text { facing the recurrence } \\
\text { of cancer }\end{array}$ & $\begin{array}{l}\text { Arruda-Colli, } \\
\text { MNF, Perina, EM, } \\
\text { Santos, MA } \\
\text { (2015) }\end{array}$ & $\begin{array}{l}\text { Recurrent } \\
\text { Cancer }\end{array}$ & $\begin{array}{l}5 \text { to } 12 \\
\text { years }\end{array}$ & $\begin{array}{l}\text { To examine } \\
\text { the different } \\
\text { perspectives of the } \\
\text { children and their } \\
\text { family } \\
\text { caregivers' } \\
\text { experiences in } \\
\text { the treatment of } \\
\text { relapsed cancer }\end{array}$ & $\begin{array}{l}\text { Sessions of the } \\
\text { Drawing-and-Story } \\
\text { Procedure analyzed } \\
\text { using content analysis }\end{array}$ & $\begin{array}{l}\text { Children evidenced } \\
\text { that they perceived the } \\
\text { threatening and uncertainty, } \\
\text { independently of their age } \\
\text { or kind of communication } \\
\text { established about the disease } \\
\text { and prognosis. The perception } \\
\text { of threat was present in all } \\
\text { participants' reports, with } \\
\text { experiences of fragility, } \\
\text { abandonment, and loneliness. }\end{array}$ \\
\hline $\begin{array}{l}\text { A14. Experiences of } \\
\text { diabetic adolescents: } \\
\text { a phenomenological } \\
\text { approach }\end{array}$ & $\begin{array}{l}\text { Cavini FL, } \\
\text { Gonçalves KA, } \\
\text { Cordeiro SM, } \\
\text { Moreira, DS, } \\
\text { Resck, ZMR } \\
(2016)\end{array}$ & Diabetes & $\begin{array}{l}12 \text { to } 18 \\
\text { years }\end{array}$ & $\begin{array}{l}\text { To unveil the } \\
\text { feelings and the } \\
\text { meaning of being } \\
\text { an adolescent with } \\
\text { diabetes mellitus } \\
\text { type } 1\end{array}$ & $\begin{array}{l}\text { Phenomenological } \\
\text { interviews }\end{array}$ & $\begin{array}{l}\text { The diagnose of diabetes have } \\
\text { impacts in children's lives in } \\
\text { relation to the life limitations } \\
\text { because of the disease. } \\
\text { Children understand the needs } \\
\text { of changing their lives in order } \\
\text { to avoid being sick. }\end{array}$ \\
\hline $\begin{array}{l}\text { A15. Experiences } \\
\text { of adolescents } \\
\text { seropositive for HIV/ } \\
\text { AIDS: a qualitative } \\
\text { study }\end{array}$ & $\begin{array}{c}\text { Galanoa, E, } \\
\text { Turatob, ER, } \\
\text { Delmasc, } \\
\text { P, Côtéd,J, } \\
\text { Gouveaa, AFTB, } \\
\text { Succia, RCMS, } \\
\text { Machadoa, DM } \\
\text { (2016) }\end{array}$ & HIV/AIDS & $\begin{array}{c}13 \text { to } 20 \\
\text { years }\end{array}$ & $\begin{array}{l}\text { Explore the } \\
\text { meanings attributed } \\
\text { by young individuals } \\
\text { about "living as an } \\
\text { adolescent with HIV" }\end{array}$ & $\begin{array}{l}\text { Qualitative research, } \\
\text { carried out through } \\
\text { interviews with open } \\
\text { questions }\end{array}$ & $\begin{array}{l}\text { Participants chose not to } \\
\text { disclose their HIV diagnose } \\
\text { to others in order to avoid } \\
\text { discrimination and fear of } \\
\text { abandonment due to prejudice. } \\
\text { The disclosure of the diagnose } \\
\text { creates feeling of "being } \\
\text { different." Beyond the illness, } \\
\text { there is a feeling of "being } \\
\text { normal"when they can share } \\
\text { same activities with people who } \\
\text { do not have the disease. }\end{array}$ \\
\hline $\begin{array}{l}\text { A16. Children and } \\
\text { adolescents living } \\
\text { with diabetes and } \\
\text { celiac disease }\end{array}$ & $\begin{array}{c}\text { Brancaglioni } \\
\text { BCA, Rodrigues } \\
\text { GC, Damião EBC, } \\
\text { Queiroz MS, } \\
\text { Nery M. } \\
\text { (2016) }\end{array}$ & Diabetes & $\begin{array}{l}9 \text { to } 18 \\
\text { years }\end{array}$ & $\begin{array}{l}\text { To understand } \\
\text { the experience } \\
\text { of children and } \\
\text { adolescents living } \\
\text { with type } 1 \text { diabetes } \\
\text { and celiac disease }\end{array}$ & $\begin{array}{l}\text { Qualitative } \\
\text { exploratory- } \\
\text { descriptive study }\end{array}$ & $\begin{array}{l}\text { Children described feelings } \\
\text { of having a "normal" life } \\
\text { when they can participate } \\
\text { in activities and play with } \\
\text { other children at school. } \\
\text { Support from family can } \\
\text { help to overcome everyday } \\
\text { challenges. }\end{array}$ \\
\hline
\end{tabular}

\section{DISCUSSION}

In relation to the results of the studies selected, four themes were identified that are related to children's moral experiences: being "normal"; social isolation and stigma; existential distress: fear and loneliness; and benefits beyond illness: valuing the ends. For the purposes of clarity, we have separated children's moral experiences into unique themes; however, because of the complex aspects of their everyday lives, aspects of children's experiences described in these themes may overlap. Themes are presented in the following discussion. The themes, selected articles, and specific health problems are charted in Chart 3.
Chart 3 - Themes

\begin{tabular}{|l|l|l|}
\hline Theme & Articles & Health problems \\
\hline Being "normal" & $\begin{array}{l}\text { A1; A2; A4; A9; A12; } \\
\text { A16; A15 }\end{array}$ & $\begin{array}{l}\text { HIV/AIDS; Sickle Cell; } \\
\text { Diabetes }\end{array}$ \\
\hline $\begin{array}{l}\text { Social isolation/ } \\
\text { stigma }\end{array}$ & $\begin{array}{l}\text { A1; A3; A4; A5; A6; A7; } \\
\text { A8; A10; A13; A15 }\end{array}$ & $\begin{array}{l}\text { HIV/AIDS; Sickle Cell; } \\
\text { Cancer }\end{array}$ \\
\hline $\begin{array}{l}\text { Existential distress: } \\
\text { death and loneliness }\end{array}$ & A7; A8; A10; A11;A13 & Cancer; HIV; Diabetes \\
\hline $\begin{array}{l}\text { Benefits beyond } \\
\text { illness: valuing the } \\
\text { ends }\end{array}$ & $\begin{array}{l}\text { A3; A4; A6; A7; A9; } \\
\text { A10; A11; A12; A13; }\end{array}$ & $\begin{array}{l}\text { HIV/AIDS; Cancer; } \\
\text { Diabetes }\end{array}$ \\
\hline
\end{tabular}




\section{Being "normal"}

In the studies analyzed, children with medical complexity showed their capacity to reflect and value their experiences regarding their feelings of normality (A16;A15;A9; A4;A2). The normal aspects were expressed by the studies as the possibilities of having future wishes, going to school, having friends, and playing. Studies (A16; A15; A9; A4; A2) demonstrated that the children consider their lives normal when they felt able to do things other children could do, despite their limitations. Furthermore, children described families and health-care providers as having an important role in keeping their'normality'by promoting activities that can prevent their isolation (A16; $A 9 ; A 4 ; A 2$ ).

The complex relation between children and families was described in the articles, with important implications for children's moral experiences. Social values transmitted to children by parents and caregivers were highlighted as important aspects to promote the feeling of normality in their lives. These values were associated with the families'fears of discrimination and prejudice, which led to a protective behavior that could isolate children. For example, articles reported that parents did not permit their child to participate in leisure activities in the school. Children's narratives expressed their perception of less negative implications of their health condition when they could enact usual actions like other children in their social environment, promoting feelings of 'being normal' (A1; $A 15 ; A 16)$.

\section{Social isolation and stigma}

The articles demonstrated children's capacity to be aware and to articulate meaningful worries and experiences in situations related to their health condition, such as isolation and discrimination (A5; A7). Although authors did not explicitly report children's choices as moral, their studies illustrated how children could value their own lived experiences as well as their capacity to understand meaningful experiences.

Negative feelings such as discrimination, prejudice, and sadness were associated with the implications of having a complex clinical condition that required constant care, hospitalizations, and medications, precluding children from interacting with others (A7; A5). Articles reported that the stigma of having a life-threatening disease such as HIV or cancer led children to isolation, causing feelings of loneliness and sadness (A7; A5).

Body changes caused by chemotherapy such as alopecia (A7) or dealing with a stigmatized condition such as HIV (A5), reflected negatively on children's self-identity, consequently creating uncertainties about their future, anguish, and isolation from others (A7; A5). Menossi \& Lima (A7) described that adolescents chose to avoid school because they felt ashamed of their hair loss. Participants also described negative feelings resulting from the impossibility of having a'normal' romantic relationship because of their health condition (A15; A7; A5).

Children chose not to socialize with others or not to go to school to prevent feeling different from friends and avoid discrimination (A15; A6). Also, children were isolated from others during school activities because they felt incapable of performing activities in the same way as others. Growing up and developing with a complex illness was considered a burden to children in these cases (A15; A10; A8; A6).
Some articles (A6; A4; A3; A1) illustrated how families provide care focused on protecting their children from discrimination. For instance, parents organized the times for taking medications when the child was at home, to prevent others from knowing their condition (A6; A4; A3; A1). Children felt afraid of exposing their diagnosis to their peers because they feared being labeled and bullied ( $A 6$; A4; A3; A1). Keeping children's diagnosis undisclosed from the child was considered by some parents as a way to protect their children from prejudice. Parents created stories such as "little animals fighting inside the child's stomach"(A6) or used a substitute condition, such as problems in the bone system, to justify the need for medications (A1).

\section{Existential distress: death and loneliness}

Articles reported children's expression of existential distress about their complex conditions (A13; A11; A8; A7). Children questioned the reasons why the complicated illness was happening to them (A13; $A 11 ; A 8 ; A 7)$, what were the implications for their future lives (A13), sought justifications for the illness (A13;A11) and feared of being alone and dying (A13; A11).

Experiences of sadness about the uncomfortable side effects of medications (A13; A11) the frequent hospitalizations with consequent breakdown of their daily routines (A13), loneliness and distance from family and friends (A7) were described negatively by these children. Hospitalization was viewed as necessary by some children because of the complexity of the treatment they required $(A 11 ; A 7)$. Feelings of loneliness were constant during hospitalizations because of detachment from people they liked, as well as the fear of being left alone in the hospital (A11;A8;A7).

Children's reflections about the possibility of dying demonstrated their existential suffering about having their lives threatened by a disease (A13). The fear of death and the perception of being too young to die created feelings of anxiety and sadness. Children also felt impotent toward death, and their fear increased when other children in the ward, such as a friend, died (A10).

\section{Benefits beyond illness: valuing the ends}

Studies presented that unpleasant means, or strategies, such as the use of medication, were accepted by children in consideration of the good results provided by these means. Examples of positive results described by children include possibilities for relieving pain, staying alive, cure, feeling healthy, going home, and being able to go to school and play. These situations were all described by the authors as positive implications that helped children to manage negative experiences, such as unpleasant taste of the medications, side effects, and painful health procedures (A14; A12; $A 11 ; A 10$; $A 9 ; A 7 ; A 6 ; A 4 ; A 3)$. Thus, children demonstrated their capacity to deliberate about meaningful situations and to reflect on their health experiences (A9; $A 7 ; A 6 ; A 4 ; A 3)$.

Studies with children living with HIV highlighted the experiences of children in relation to their antiretroviral treatment. These experiences ranged from negative feelings related to discomforts caused by the side effects of these medications, discrimination, and fear of death (A4), to the positive feelings of staying alive and avoiding hospitalization and death (A9; A7; A6; A3). In these situations, children were able to demonstrate 
that something bad (use of medication) was justified in relation to something good (staying alive). This situation increased their adherence to treatment (A12;A6; A4; 33$)$.

Health experiences of children with cancer included difficulties concerning their hospitalization and clinical condition, such as physical pain and being alone (A7). Besides such problems, children described the possibilities of diminishing suffering and cure that came from their medical care and hospitalizations. This understanding about the good ends of the process of chemotherapy and hospitalization led children to cooperate with health practices and to better accept the treatment (A10;A7).

\section{Limitations of study}

This study has limitations considering the use of articles only written in Portuguese and English language. Another limitation is that this review was conducted in one limited setting regarding the Brazilian perspectives on children's moral experiences. Besides, as we understand Brazil as a vast country with many cultural, social, and economic differences, not including information on the specific region of Brazil where researchers conducted these studies is another limitation. Importantly, though we provided here an important reflection on the Brazilian's perspectives, we cannot anticipate how the results would translate in different settings. To conclude, the selection and screening of the final articles included in the analysis were done by only one reviewer, constituting a further limitation to this study.

\section{Contributions to health-related research}

The evidence synthesized in this review is a first step in the development of research concerned with the moral lives of children with medical complexity, and how the different social contexts shape these experiences. The results showed the importance of understanding children's experiences in relation to their own views and interpretations in order to provide care that can meet their needs. In addition, we suggest that the use of a more explicit framework to address the moral concerns of children with medical complexity can foster understanding of their preferences. Such a framework can help orient health researchers, as well as other researchers from interdisciplinary perspectives, to elicit and understand children's views, values, and interpretations.

\section{FINAL CONSIDERATIONS}

The evidence about the moral experiences of children with medical complexity within Brazilian health-related research is limited. Despite that, our analysis found many morally relevant accounts within this literature. Researchers regarded children as participants in their studies, engaging with the analysis of children's lived experiences through the children's own voices. These studies have also emphasized the importance of giving children space to display their experiences. In their accounts, children demonstrated their capacity to reflect on moral concerns related to the illness process, engaging with conversations about complex matters, such as stigma, loneliness, and fear of death.

Importantly, although the studies were describing morally relevant accounts of children with medical complexity, none of the articles presented a clear framework for addressing children's experiences. Frameworks used came primarily from nursing research and qualitative research in general.

The identified studies focused primarily on children's experiences regarding their illness process in a broad approach. Thus, the knowledge about the moral implications of the health experiences of children with medical complexity is still restricted in Brazilian health-related literature. Further work is needed to address the moral concerns regarding the lives of children with medical complexity through the development of studies using an explicit conceptualization of moral experiences.

Another research gap found in our analysis was the limited interdisciplinary scope of the literature analyzed. In our analysis, 15 of the 16 articles were nursing studies. Therefore, we suggest that future interdisciplinary research is needed to improve health research and health-care practices by uncovering children's views on moral concerns from multiple perspectives. It is hoped that this exploration of moral experiences of children with medical complexity in Brazil will foster the interest of researchers from various disciplinary fields in understanding and exploring this important dimension of child care.

\section{FUNDING}

The authors disclosed receipt of the following financial support for the research, authorship, and/or publication of this article: This work was supported by the 2015-2016 McGill McCutcheon Pediatric Palliative Care Doctoral Scholarship.

\section{ACKNOWLEDGEMENT}

The authors would like to acknowledge the nursing librarian Francesca Frati who kindly collaborated in the development of the search strategy for this review.

\section{REFERENCES}

1. Cohen E, Kuo DZ, Agrawal R, Berry JG, Bhagat SKM, Simon TD, et al. Children with medical complexity: An emerging population for clinical and research initiatives. Pediatrics. 2012;127(3): 529-538. doi: 10.1542/peds.2010-0910

2. Pediatric Complex Care Association. Children and young adults with medical complexity: Serving an emerging population. [Internet]. 2016 [cited 2019 Feb 5]. Available at: http://pediatriccomplexcare.org/wp-content/uploads/2016/03/PCCA-CMSWhitePaper012716.pdf

3. Miranda AMD, Cunha DIB, Gomes SMF. The influence of technology in newborn survival of extremely premature infants with very low weight: integrative review. Rev Min Enferm. 2010;14(3):435-442. doi: S1415-27622010000300019 
4. Neves ET, Silveira AD, Arrué AM, Pieszak GM, Zamberlan KC, Santos RP. Network of care of children with special health care needs. Texto Contexto Enferm. 2015;24(2):399-406. doi: 10.1590/0104-07072015003010013

5. Montreuil M, Noronha C, Floriani N, Carnevale FA. Children's moral agency: an interdisciplinary scoping review. J Childhood Stud. 2018;43(2):7-30. doi: 10.18357/jcsv43i2.18575

6. Bubadué RDM, Cabral IE, Carnevale F, Asensi FD. Normative analysis of the voice of children in Brazilian child protection legislation. Rev Gaúcha Enferm. 2016;37(4):e58018. doi: 10.1590/1983-1447.2016.04.58018

7. Carnevale FA, Campbell A, Collin-Vezina D, et al. Interdisciplinary studies of childhood ethics: Developing a new field of inquiry. Children Soc. 2015;29(6):511-523. doi: 10.1111/chso.12063

8. Montreuil M, Carnevale FA. Participatory hermeneutic ethnography: A methodological framework for health ethics research with children. Qual Health Res. 2018;28(7):1135-44. doi: 10.1177/1049732318757489

9. Hunt MR, Carnevale FA. Moral experience: A framework for bioethics research. J Med Ethics. 2011;37(11):658-662. doi: 10.1136/ jme.2010.039008

10. Arksey H, O'Malley L. Scoping studies: towards a methodological framework. Int J Soc Res Methodol. 2005;8(1):19-32. doi: $10.1080 / 1364557032000119616$

11. Peterson J, Pearce PF, Ferguson LA, Langford CA. Understanding scoping reviews: Definition, purpose, and process. J Am Assoc Nurse Pract. 2017;29(1):12-16. doi: 10.1002/2327-6924.12380

12. Araújo JP, Silva RMM, Collet N, Neves ET, Oliveira TBRG, Viera CS. History of the child's health: conquers, policies and perspectives. Rev Bras Enferm. 2014;67(6):1000-7. doi: 10.1590/0034-7167.2014670620

13. Tricco AC, Lillie E, Zarin W, O'Brien KK, Colquhoun H, Levac D, et al. PRISMA extension for scoping reviews (PRISMA-ScR): checklist and explanation. Ann Intern Med. 2018;169(7):467-73. doi: 10.7326/M18-0850

14. Carnevale FA. Charles Taylor, hermeneutics and social imaginaries: a framework for ethics research. Nurs Philos. 2013;14(2):86-95. doi: $10.1111 /$ j.1466-769X.2012.00547x 